Eur. J. Clin. Chem. Clin. Biochem.

Vol. 31, 1993, pp. 683-687

(C) 1993 Walter de Gruyter \& Co.

Berlin $\cdot$ New York

\title{
Rapid Screening of Low Molecular Mass Proteinuria: Evaluation of the First Immunochemical Test Strip for the Detection of $\alpha_{1}$-Microglobulin in Urine
}

\author{
By K. Jung ${ }^{1}$, Monika Pergande ${ }^{1}$, F. Priem ${ }^{2}$, Sabine Becker ${ }^{1}$ and Silke Klotzek ${ }^{1}$ \\ 1 Klinik für Urologie \\ ${ }^{2}$ Institut für Pathologische und Klinische Biochemie \\ Universitätsklinikum Charité, Humboldt-Universität zu Berlin, Germany
}

(Received May 24/July 12, 1993)

\begin{abstract}
Summary: A new semiquantitative immunochemical test strip for urinary $\alpha_{1}$-microglobulin, a marker protein for tubular proteinuria, was assessed. This test strip has four colour zones, reflecting $\alpha_{1}$-microglobulin concentrations of ca. $10,25,50$, and $80 \mathrm{mg} / \mathrm{l} . \alpha_{1}$-Microglobulin concentrations were measured by means of the test strip and an immunonephelometric method in 330 samples collected as the second voided morning urine. The reading time of the test strip must be strictly observed. Reading one minute earlier or later than the $5 \mathrm{~min}$ stated in the instructions led to misclassification of over $70 \%$ of the results. Correlation between both methods was highly significant, with a Spearman rank correlation coefficient of $r_{s}=0.84(P<0.001)$. There was a partial overlap of the test strip results in different concentration ranges. An elevation of $\alpha_{1}$ microglobulin was defined as $>25 \mathrm{mg} / 1$, calculated as the upper limit of the central $95 \%$ interval of $\alpha_{1}$ microglobulin concentration in urine samples measured in a previous study of 304 healthy adults. Using this definition of $\alpha_{1}$-microglobulin elevation, a sensitivity of $97.5 \%$, specificity of $73.6 \%$, a false-positive rate of $16.6 \%$, and a false-negative rate of $0.9 \%$ of the test strip results were obtained. A fraction of $82.4 \%$ of the 330 samples investigated was correctly classified as having increased $\alpha_{1}$-microglobulin concentration or not. Methodical improvements of the test strip are necessary to reduce overlapping results, in order to make the test suitable for screening purposes.
\end{abstract}

\section{Introduction}

Since the onset of renal tubular damage is often not preceded by other warning signs of renal dysfunction, it has been suggested that the measurement of low molecular mass proteins in urine should be used as an indicator of renal dysfunction $(1,2)$. Low molecular mass proteins such as $\beta_{2}$-microglobulin, retinol binding protein, ribonuclease, and $\alpha_{1}$-microglobulin have been recommended as potential markers for detecting this type of proteinuria, which is known as tubular or low molecular mass proteinuria (3). Several authors have reported the advantages of $\alpha_{1}$-microglobulin in comparison with the conventional marker $\beta_{2}$-microglobulin (4-8). However, current methods like enzyme immunoassays, single radial immunodif- fusion, and nephelometric techniques described for laboratory measurement of this protein are not suitable as screening procedures (6). Simple approaches, such as the Micral-Test strip for microalbuminuria $(9-11)$, which is easy to apply and yields quick results, would be useful.

The objective of this study was to evaluate a recently developed immunochemical test strip for $\alpha_{1}$-microglobulin in urine as a means of detecting low molecular mass proteinuria. We assessed the possible discrimination power of this test for normal and increased values of $\alpha_{1}$-microglobulin in urine by comparing semiquantitative test strip with quantitative immunonephelometric results for different reference intervals of this protein. 


\section{Materials and Methods}

\section{Patients and urine samples}

Urine samples from patients of a renal outpatient department and of the departments of internal medicine, surgery and urology were used. The strip testing for $\alpha_{1}$-microglobulin was performed with 330 urine samples within four hours on the day of collection. Second morning urine samples collected between 07.00 and 10.00 hours were used (12).

\section{Test strip principle}

The strip is an immunoassay based on the principle already successfully used in Micral-Test and developed by Boehringer Mannheim GmbH (Mannheim, Germany) (fig. 1). The test strip is dipped into the urine sample for $5 \mathrm{~s}$ and the colour is read after $5 \mathrm{~min} . \alpha_{1}$-Microglobulin of the urine sample is chromatographed through the wick fleece, adjusted in the buffer fleece to neutral $\mathrm{pH}$ and forms a complex with a soluble conjugate of $\alpha_{1}$-microglobulin-antibody and $\beta$-galactosidase (EC 3.2.1.23). This $\alpha_{1}$-microglobulin-antibody-enzyme complex moves to the capture matrix containing immobilized $\alpha_{1}$-microglobulin where excess antibodies are removed so that only the complex of conjugate with the $\alpha_{1}$-microglobulin of the urine sample moves to the substrate film zone. In this pad, the substrate, $3^{\prime}, 3^{\prime \prime}$-dichlorophenolsulphophthaleinyl- $\beta$-galactopyranoside, is cleaved by the marker enzyme $\beta$-galactosidase, thus forming a yellow to red colour. The colour development is proportional to the $\alpha_{1}$-microglobulin concentration in urine. Comparison with four different colour blocks corresponding to concentrations of ca. $10,25,50$ and $80 \mathrm{mg} / \mathrm{l}$, is used for the semiquantitative determination of the $\alpha_{1}$-microglobulin concentration.

\section{Test strip evaluation}

The test strip readings were carried out by two technicians experienced in reading reagent strips, and they were specially trained in the use of these particular test strips; approved guidelines for the evaluation of reagent strips were taken into account $(13,14)$. According to the instructions given by the manufacturer, the upward reading principle was used. The influence of the contact time of the test strip with urine and the effect of the reading time on colour classification was evaluated by varying these respective times.

\section{Comparative method}

$\alpha_{1}$-Microglobulin was determined quantitatively by immunonephelometry, using reagents (analyser reagent, OWLA 10; protein standard urine concentrate, OUUM 02/03) and the BNA 100 analyser from Behring AG (Marburg, Germany). The interassay coefficient of variation was $1.4 \%$ for the immunonephelometric assay $(n=14)$ with control materials of 24.1 $\mathrm{mg} / \mathrm{l}$.

Creatinine was determined by a continuous assay with alkaline picrate.

\section{Statistical analyses}

The statistical packages of SPSS/PC +4.0 (SPSS Inc., Chicago, IL, USA) and Statgraphics 5.01 (Statistical Graphics Corp., Rockville, ML, USA) were used for calculation.

\section{Results}

Test strip results compared with immunonephelometric measurements

The comparison between the test strip and the quantitative immunonephelometric assay is given in figure 2 and table 1 . The correlation between the two methods is characterized by a Spearman rank correlation coefficient of $r_{s}=0.84(P<0.001)$. Although the comparison of the semiquantitative test strip results is strictly speaking only justified for the concentration alone (fig. 2a), we also illustrate the results in comparison with the protein/creatinine ratio (fig. $2 b$ ). There is a partial overlap between the test strip results in different ranges of concentrations (tab. 1, fig. 2).

\section{Intra- and inter-observer variation of the test}

Five samples (two below $10 \mathrm{mg} / \mathrm{l}$ and three above 30 $\mathrm{mg} / \mathrm{l} \alpha_{1}$-microglobulin) were read 8 times by one observer and 50 urine samples $\left(8.4 / 76.3 \mathrm{mg} / 1 \alpha_{1}\right.$-microglobulin) were separately tested by two observers. There was more than $92 \%$ agreement between the different observers. Where differences occurred, these were in the assessment of the higher $\alpha_{1}$-microglobulin concentrations. However, the variation did not exceed one colour category and no sample was misclassified as normal or pathological.

\section{Effect of contact time and reading time of the test strip result}

The manufacturer's intructions state that the strip should be dipped into urine for $5 \mathrm{~s}$ and the colour should be read after $5 \mathrm{~min}$. The influence of the contact time was tested at 3,5 and $7 \mathrm{~s}$ and the reading time at 4,5 and $6 \mathrm{~min}$. When the strips were dipped into urine for either $3 \mathrm{~s}$ or $7 \mathrm{~s}$, three out of 20 tested samples were classified by colour zones one category lower, and two were one category higher, respectively.

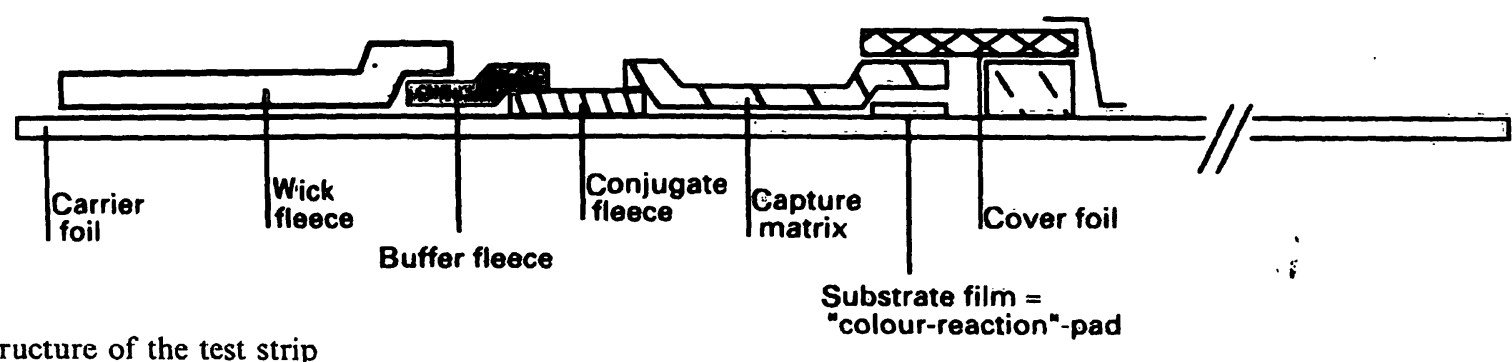

Fig. 1. Structure of the test strip 

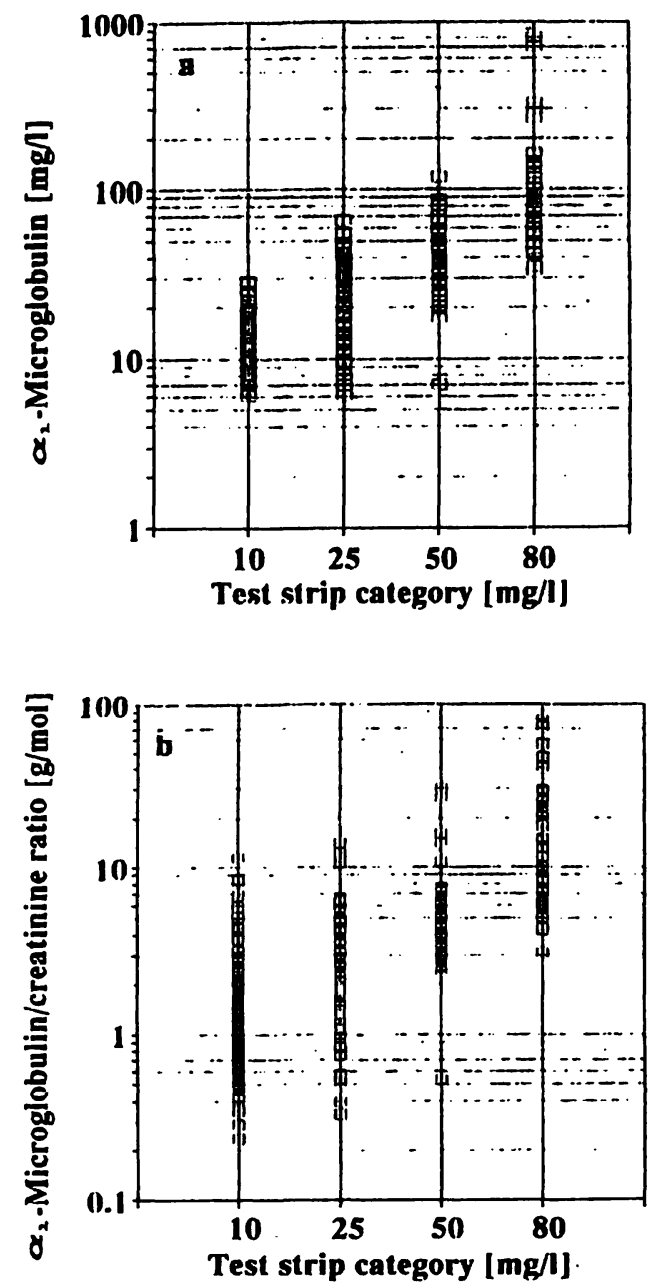

Fig. 2. Test strip results versus $\alpha_{1}$-microglobulin concentrations (a) and versus $\alpha_{1}$-microglobulin/creatinine ratios (b), measured by immunonephelometric assay of 330 urine samples

The results were especially influenced by the reading time of the test. By reading the 20 samples at $4 \mathrm{~min}$ or $6 \mathrm{~min}$, the results were decreased (16 samples) or increased (15 samples), respectively, by at least one colour zone.

\section{Diagnostic validity}

As a rational basis for the evaluation of the $\alpha_{1}$-microglobulin test strip, we used reference intervals for $\alpha_{1}$-microglobulin, expressed as concentrations and protein/creatinine ratios, which where determined in a previous study (15). Briefly, we found that $\alpha_{1}$-microglobulin concentrations varied with sex and age, and $\alpha_{1}$-microglobulin/creatinine ratios varied with age but not with sex. The $95 \%$ central reference intervals according to the percentile approach recommended by IFCC (16) were calculated and the upper $95 \%$ reference limits of combined and statistically identical groups were used as cutoff levels (tab. 2). For clinical practice, we recommend the use of combined upper
Tab. 1. Classification of test strip results in comparison with $\alpha_{1}$-microglobulin concentrations measured by immunonephelometry.

\begin{tabular}{lllll}
\hline $\begin{array}{l}\text { Test strip } \\
\text { category } \\
(\mathrm{mg} / \mathrm{l})\end{array}$ & \multicolumn{4}{c}{$\alpha_{1}$-Microglobulin concentration $(\mathrm{mg} / \mathrm{l})$} \\
\cline { 2 - 6 } & $0-10.0$ & $10.1-25.0$ & $25.1-50.0$ & $>50.0$ \\
\hline 10 & 97 & 56 & 3 & \\
25 & 6 & 41 & 30 & 2 \\
50 & 1 & 7 & 21 & 14 \\
80 & - & - & 6 & 46 \\
\hline
\end{tabular}

Tab. 2. Cutoff limits for $\alpha_{1}$-microglobulin in urine taken from a previous study (15). ${ }^{\mathrm{a}}$

\begin{tabular}{|c|c|c|c|}
\hline \multicolumn{2}{|c|}{ Groups } & \multirow[t]{2}{*}{ Median } & \multirow{2}{*}{$\begin{array}{l}\text { 95th } \\
\text { percentiles }\end{array}$} \\
\hline Sex & Age (years) & & \\
\hline \multirow{6}{*}{ 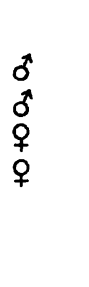 } & & \multicolumn{2}{|c|}{ Concentration $(\mathrm{mg} / \mathrm{l})$} \\
\hline & $18-49 ;>50$ & 5.0 & 26.1 \\
\hline & $41-50$ & 13.9 & 23.4 \\
\hline & $>40$ & 6.9 & 28.0 \\
\hline & $18-40$ & 2.3 & 14.7 \\
\hline & & \multicolumn{2}{|c|}{$\begin{array}{l}\alpha_{1}-\text { Microglobulin/creatinine } \\
\text { ratio }(\mathrm{g} / \mathrm{mol})\end{array}$} \\
\hline $9,0^{\pi}$ & $18-40$ & 0.22 & 1.27 \\
\hline 9,8 & $>40$ & 0.64 & 2.20 \\
\hline
\end{tabular}

a The study was performed on 304 healthy adults (144 women, 160 men). All subjects had no history of renal diseases, were asymptomatic at the time, and were not receiving medication; results of urine analysis with Combur-9-Test strips (Boehringer Mannheim GmbH, Mannheim, Germany) were negative and serum creatinine concentrations were below $106 \mu \mathrm{mol} / \mathrm{l}$ (15).

cutoff values based on concentrations for all male adults and females over 40 years and a differentiation of the type indicated in table 2 when the $\alpha_{1}$-microglobulin/creatinine ratio is used.

Under the precondition that the test strip results of $10 \mathrm{mg} / \mathrm{l}$ are considered negative and results of 25,50 , and $80 \mathrm{mg} / \mathrm{l}$ positive, the diagnostic validity data according to the reference limits presented in table 2 are shown in table 3. For the upper cutoff limits of $15 \mathrm{mg} / \mathrm{l}$ or $25 \mathrm{mg} / \mathrm{l}, 86.1 \%$ and $82.4 \%$ of the samples investigated were correctly classified as having an increased $\alpha_{1}$-microglobulin concentration or not. The corresponding values for the $\alpha_{1}$-microglobulin/creatinine ratio of 1.25 or $2.20 \mathrm{~g} / \mathrm{mol}$ were generally lower and amounted to $74.8 \%$ and $79.4 \%$, respectively.

The cutoff limit of $25 \mathrm{mg} / \mathrm{l}$ (identified as a suitable upper limit during the establishment of reference values) gave a sensitivity of $97.5 \%$, specificity of $73.6 \%$, a false-positive rate of $16.6 \%$ (55 out of 330), and a false-negative rate of $0.9 \%$ ( 3 out of 330 ). 
Tab. 3. Validity of test strip results at various cutoff limits determined by immunonephelometric assay. ${ }^{\text {a }}$

\begin{tabular}{|c|c|c|c|c|c|c|c|c|c|}
\hline $\begin{array}{l}\text { Cutoff } \\
\text { limit } \\
\text { by } \\
\text { immunone- } \\
\text { phelometry }\end{array}$ & $\begin{array}{l}\text { True } \\
\text { posi- } \\
\text { tives }\end{array}$ & $\begin{array}{l}\text { False } \\
\text { nega- } \\
\text { tives }\end{array}$ & $\begin{array}{l}\text { True } \\
\text { nega- } \\
\text { tives }\end{array}$ & $\begin{array}{l}\text { False } \\
\text { posi- } \\
\text { tives }\end{array}$ & $\begin{array}{l}\text { Sensi- } \\
\text { tivity } \\
(\%)\end{array}$ & $\begin{array}{l}\text { Speci- } \\
\text { ficity } \\
(\%)\end{array}$ & $\cdot 1$ & $\begin{array}{l}\text { Nega- } \\
\text { tive } \\
\text { predic- } \\
\text { tive } \\
\text { value } \\
(\%)\end{array}$ & $\begin{array}{l}\text { Posi- } \\
\text { tive } \\
\text { predic- } \\
\text { tive } \\
\text { value } \\
(\%)\end{array}$ \\
\hline $\begin{array}{l}15 \mathrm{mg} / \mathrm{l} \\
25 \mathrm{mg} / \mathrm{l} \\
1.25 \mathrm{~g} / \mathrm{mol}^{\mathrm{b}} \\
2.20 \mathrm{~g} / \mathrm{mol}^{2}\end{array}$ & $\begin{array}{l}155 \\
119 \\
155 \\
129\end{array}$ & $\begin{array}{r}27 \\
3 \\
64 \\
23\end{array}$ & $\begin{array}{r}129 \\
153 \\
92 \\
133\end{array}$ & $\begin{array}{l}19 \\
55 \\
19 \\
45\end{array}$ & $\begin{array}{l}85.2 \\
97.5 \\
73.5 \\
84.9\end{array}$ & $\begin{array}{l}87.2 \\
73.6 \\
82.9 \\
74.7\end{array}$ & & $\begin{array}{l}82.7 \\
98.1 \\
58.9 \\
85.3\end{array}$ & $\begin{array}{l}89.1 \\
68.4 \\
89.1 \\
74.1\end{array}$ \\
\hline
\end{tabular}

a The $10 \mathrm{mg} / \mathrm{l}$ test strip category was considered negative, the other colour blocks positive.

b $\alpha_{1}$-Microglobulin per mol urinary creatinine.

\section{Discussion}

The present study is the first successful attempt to detect low molecular mass proteinuria with a test strip. Until recently, only sophisticated laboratory methods (enzyme and radio immunoassays, single radial immunodiffusion, nephelometric techniques) were available for detection of tubular proteins (6). As these proteins are sensitive indicators of tubular dysfunction and usually occur long before serum creatinine elevations or general proteinuria become evident, the laboratory diagnostic programme for detection of renal diseases should include a tubular marker protein $(17,18)$. Low molecular mass proteinuria is found under numerous clinical conditions, in which the proximal kidney tubules are primarily affected (2). Nephrotoxic effects of drugs such as aminoglycoside antibiotics and environmental pollutants such as cadmium or lead are of special importance and early warning of impending kidney problems may be gained by screening these risk patients (2).

$\alpha_{1}$-Microglobulin was selected as the tubular protein for a test strip for diagnostic, preanalytical, and analytical reasons:

- $\alpha_{1}$-microglobulin indicates tubular damage earlier than other low molecular mass proteins (12),

$-\alpha_{1}$-microglobulin is more stable in urine than the conventional tubular protein $\beta_{2}$-microglobulin if the urinary $\mathrm{pH}$ is less than $5.5(4,5)$,

$-\alpha_{1}$-microglobulin concentration is about $20 \mathrm{mg} / \mathrm{l}$ in normal urine, being higher than that of other tubular proteins, which greatly facilitated the development of a test strip.

From the analytical point of view, it is important that the reading time of 5 min must be strictly observed. Reading one minute earlier or later than the $5 \mathrm{~min}$ stated in the manufacturer's instruction led to misclassification of over $70 \%$ of the results. The reading time had less influence on the Micral-Test (9).
There was a good correlation between the semiquantitative test strip and the quantitative measurements, although some overlapping results were obtained. Thus, the diagnostic validity data are particularly dependent on the cutoff point (tab. 3). Different reference ranges for urinary $\alpha_{1}$-microglobulin are reported in the literature $(4,6-8,15,17-19)$. This is due, inter alia, to the use of calibration material and antisera of different specificity in the immunochemical methods (radioimmunoassay, enzyme immunoassay, radial immunodiffusion), probably caused in turn by the heterogenous nature of $\alpha_{1}$-microglobulin (15). We therefore used own reference limits established in a large group of healthy adults for the evaluation of this test strip (tab. 2).

For the characterization of protein excretion in random urine samples, the use of protein/creatinine ratio is suggested, because it makes allowance for the influence of urine flow rate on the concentration of the respective protein (1). However, as all dipstick tests rely on measuring only the concentration of the analyte, there is a general limitation of these tests which should always be taken into account regardless of which cutoff limit is used. Thus, it is not surprising that the test strip is less sensitive and less specific for the discrimination of protein/creatinine ratios rather than concentrations.

If elevated urinary $\alpha_{1}$-microglobulin is defined $>25$ $\mathrm{mg} / \mathrm{l}$, which we believe would be acceptable as a reasonable screening level, then the positive and negative test strip results correctly classified $82.4 \%$ of the samples as having or not having elevated $\alpha_{1}$-microglobulin concentrations. At this cutoff, resulting in a sensitivity of $97.5 \%$ and a negative predictive value of $98.1 \%$, only a few samples with elevated $\alpha_{1}$-microglobulin concentration were not recognized. The specificity of $73.6 \%$ and the positive predictive value of $68.4 \%$ indicates that some fallse positive results are to be expected, and most of these are registered on the $25 \mathrm{mg} / \mathrm{l}$ colour block. Subjects with positive test 
strip results should receive further testing with a quantitative laboratory measurement. The validity data of the $\alpha_{1}$-microglobulin test strip are slightly worse than results obtained with the Micral-Test but comparable to other screening approaches for microalbuminuria.

In conclusion, we believe that the $\alpha_{1}$-microglobulin test strip offers a suitable principle for detecting low molecular mass proteinuria. However, if the test is to be used for screening purposes, methodical improvements of the test strip are necessary to reduce the number of overlapping results and to establish the

\section{References}

1. Cohen, E. P. \& Lemann, J. (1991) The role of the laboratory in evaluation of kidney function. Clin. Chem. 37, 785-796.

2. Wibell, L. (1985) Aspects on tubular proteinuria. Upsala J. Med. Sci. 90, 5-14.

3. Jung, K., Pergande, M., Schulze, B. D., Precht, K. \& May, G. (1989) Niedermolekulare Proteine im Serum und Urin bei nephrologischen Fragestellungen. Z. Klin. Med. 44, $549-556$.

4. Yu, H., Yanagishawa, Y., Forbes, M. A., Cooper, E. H., Crockson, R. A. \& Maclennan, I. C. M. (1983) Alpha-1microglobulin: An indicator protein for renal tubular function. J. Clin. Pathol. 36, 253-259.

5. Donaldson, M. D. C., Chambers, R. E., Woolridge, M. W. \& Whicher, J. T. (1989) Stability of alpha-1-microglobulin, beta-2-microglobulin and retinol binding protein in urine. Clin. Chim. Acta 179, 73-78.

6. Itoh, Y. \& Kawai, T. (1990) Human alpha 1-microglobulin: Its measurement and clinical significance. J. Clin. Lab. Anal. 4, 376-384.

7. Flynn, F. V. (1990) Assessment of renal function: selected developments. Clin. Biochem. 23, 49-54.

8. Weber, M. H. \& Verwiebe, R. (1992) $\alpha_{1}$-Microglobulin (protein hc): Features of a promising indicator of proximal tubular dysfunction. Eur. J. Clin. Chem. Clin. Biochem. $30,683-691$.

9. Marshall, S. M., Shearing, P. A. \& Alberti, K. G. M. M. (1992) Micral-test strips evaluated for screening for albuminuria. Clin. Chem. 38, 586-591.

10. Schaufelberger, H., Caduff, F., Engler, H. \& Spinas, G. A. (1992) Evaluation eines Streifentests (Micral-Test) zur semiquantitativen Erfassung der Mikroalbuminurie in der Praxis. Schweiz. Med. Wochenschr. 122, 576-581. pathological significance of positive test strip results, especially in the $25 \mathrm{mg} / \mathrm{l}$ category. A test strip such as this could especially improve the early detection of renal damage in high-risk persons like heavy metal workers or patients treated with nephrotoxic drugs.

\section{Acknowledgement}

This work was supported by funds from the German Federal Ministry of Research and Technology (Grant No. 01 HK 2618) and from the University Hospital Charite of the Humboldt University Berlin. We thank Boehringer Mannheim GmbH for the test strips and permission to use figure 1.

11. Jury, D. R., Mikkelsen, D. J.. Glen, D. \& Dunn, J. P. (1992) Assessment of micral-test microalbuminuria test strip in the laboratory and in diabetic outpatients. Ann. Clin. Biochem. 29, $96-100$.

12. Jung, K. (1991) Zur Wahl der Urinprobe, Bezugsgröße und Kenngröße bei tubulären Proteinurien. In: Pathobiochemie und Funktionsdiagnostik der Niere (Guder, W. G. \& Lang, H., eds.) pp. $201-210$, Springer, Berlin.

13. Bandi, Z. L., Myers, J. L., Bee, D. E. \& James, G. P. (1982) Evaluation of determination of glucose in urine with some commercially available dipsticks and tablets. Clin. Chem. 28, 2110-2115.

14. Berg, B., Hellsing, K., Jagenburg, R. \& Kallner, A. (1989) Guidelines for evaluation of reagent strips. Exemplified by analysis of urine albumin and glucose concentration. Scand. J. Clin. Lab. Invest. 49, 689-699.

15. Jung, K., Pergande, M., Schreiber, G. \& Thierfelder, W. (1992) Reference intervals for $\alpha_{1}$-microglobulin in urine. Clin. Chim. Acta 206, 245-247.

16. Solberg, H. E. (1987) Approved recommendation (1987) on the theory of reference values. Part 5. Statistical treatment of collected reference values. Determination of reference limits. J. Clin. Chem. Clin. Biochem. 25, 645-656.

17. Weber, M. H., Scholz, P., Stibbe, W. \& Scheler, F. (1985) Alpha-1-mikroglobulin im Urin und Serum bei Proteinurie und Niereninsuffizienz. Klin. Wochenschr. 63, 711-719.

18. Hofmann, W. \& Guder, W. G. (1989) A diagnostic programme for quantitative analysis of proteinuria. J. Clin. Chem. Clin. Biochem. 27, 589-600.

19. Itoh, Y., Nishino, H., Enomoto, H. \& Kawai, T. (1986) A double antibody radioimmunoassay for human $\alpha_{1}$-microglobulin. Clin. Chim. Acta 155, 221-226.

Dr. Klaus Jung
Forschungsabteilung der Klinik für Urologie
Universitätsklinikum Charité
Humboldt-Universität zu Berlin
Schumannstraße 20/21
D-10098 Berlin
Germany


$$
\text { . }
$$ 